$0.012 \sim 0.132, \quad P=0.018)$ and trunk $B F \% \quad(\beta=0.152,95 \% \mathrm{Cl} 0.043 \sim 0.261$, $P=0.007$ ), but not limb BF\%, were positively correlated with sUA.

\begin{tabular}{|c|c|c|c|c|c|c|c|}
\hline \multicolumn{8}{|c|}{ Figure 1 Clinical characteristics and body composition of gout patients } \\
\hline \multirow[b]{2}{*}{ characteristics } & \multirow{2}{*}{$\begin{array}{c}\text { All patients } \\
(n=362)\end{array}$} & \multicolumn{3}{|c|}{ Grouped by gender } & \multicolumn{3}{|c|}{ Male patients grouped by overfat } \\
\hline & & $\begin{array}{c}\text { Malo } \\
(n=348)\end{array}$ & $\begin{array}{c}\begin{array}{c}\text { Female } \\
(n=14)\end{array} \\
\text { (n) }\end{array}$ & p & $\begin{array}{l}\text { Ovorfat } \\
(n=187)\end{array}$ & $\begin{array}{c}\text { Non-ovorat } \\
(n=161)\end{array}$ & P \\
\hline Age, years & $38(30,52)$ & $38(30,50)$ & $66(59,72)$ & $<0.001$ & $38(30,51)$ & $37(30,50)$ & 0.969 \\
\hline Duration, years & $3(2,7)$ & $3(2,7)$ & $3(1,6)$ & 0.423 & $4(2,7)$ & $3(1,6)$ & 0.163 \\
\hline Count of affecting joints & $3(2,6)$ & $3(2,6)$ & $3(1,5)$ & 0.494 & $4(2,6)$ & $2(2,5)$ & 0.002 \\
\hline Family history, $\mathrm{n}(\%)$ & 130(35.9) & 124(35.6) & $6(42.9)$ & 0.581 & $74(39.6)$ & $50(31.1)$ & 0.098 \\
\hline Tophi, n(5) & $65(18.0)$ & $64(18.4)$ & $1(7.1)$ & 0.472 & $36(19.3)$ & $28(17.4)$ & 0.655 \\
\hline Serum uric acid, mz/dal & $9.2 \pm 2.2$ & $9.2 \pm 2.2$ & $9.2 \pm 2.5$ & 0.957 & $9.6 \pm 2.1$ & $8.7 \pm 2.2$ & $<0.001$ \\
\hline eGFR, $\mathrm{ml} / \mathrm{min}-1 / 1.73 \mathrm{~m}-2$ & $83.8+17.0$ & 84.3416 .9 & $70.4 \pm 11.7$ & 0.002 & $85.1 \pm 18.2$ & 83.5415 .3 & 0.395 \\
\hline Urolithiasis, n (\%) & 88(24.3) & $85(24.4)$ & $3(21.4)$ & 0.795 & $49(26.2)$ & $36(22.4)$ & 0.405 \\
\hline Hypertension, $n(*)$ & $133(36.7)$ & 122(35.6) & $9(64.3)$ & 0.029 & $83(44.4)$ & $41(25.5)$ & $<0.001$ \\
\hline Dibbetes mellitus, $n$ (\%) & $36(9.9)$ & $33(9.5)$ & 3(21.4) & 0.313 & $23(12.3)$ & ${ }^{10(6.2)}$ & 0.053 \\
\hline Dystipidemia, n (F) & $22863.0)$ & $2188(2.6)$ & $10(71.4)$ & 0.504 & $131(70.1)$ & $87(54.0)$ & 0.002 \\
\hline Body masss index, kg/m2 & 25.543 .6 & $\begin{array}{l}25.533 .6 \\
77202711\end{array}$ & $25.7 \pm 3.1$ & 0.382 & 27.433 .3 & $23.3 \pm 2.6$ & $<0.001$ \\
\hline $\begin{array}{l}\text { obesity n n(s) } \\
\text { Waist cirumstance, cm }\end{array}$ & $79(21.8)$ & $\begin{array}{l}77(22.1) \\
90.89 .5\end{array}$ & $\begin{array}{l}2(2.5) \\
89.370\end{array}$ & 0.392 & $73(39.0)$ & $\begin{array}{c}4(2.5) \\
85.072\end{array}$ & $<0.001$ \\
\hline $\begin{array}{l}\text { Waist cirruunstance, } \mathrm{cm} \\
\text { Metabolic syndrome } n(\%)\end{array}$ & $\begin{array}{l}90.859 .4 \\
1155.45\end{array}$ & $\begin{array}{l}90.889 .5 \\
158(95.9)\end{array}$ & $\begin{array}{l}89.377 .4 \\
7(50.0)\end{array}$ & $\begin{array}{l}0.551 \\
0.735\end{array}$ & $\begin{array}{r}95.9 \pm 8.3 \\
114610\end{array}$ & $\begin{array}{l}85.0 \pm 7.2 \\
0427.3\end{array}$ & $<0.001$ \\
\hline $\begin{array}{l}\text { Fatty liver, } n(\%) \\
\text { (\%) }\end{array}$ & $172(47.5)$ & $\begin{array}{l}165(47.94) \\
1.94\end{array}$ & $7(50.0)$ & 0.849 & $108[57.8]$ & $57(35.4)$ & $\begin{array}{l}<0.001 \\
<0.001\end{array}$ \\
\hline Coronary heart disease, $n(\%)$ & $3(2.2)$ & $6(1.7)$ & $2(14.3)$ & 0.027 & $1(0.5)$ & $5(3.1)$ & 0.100 \\
\hline $\mathrm{BF} \%, \%$ & $25.8 \pm 6.4$ & 25.546 .2 & $35.0 \pm 5.0$ & $<0.001$ & $30.1 \pm 3.8$ & $20.1+3.7$ & $<0.001$ \\
\hline Overfat, $n(\%)$ & $194(53.6)$ & $187(53.7)$ & $7(50.0)$ & 0.783 & $187(100)$ & $0(0)$ & $<0.001$ \\
\hline Trunk BF\%,\% & $13.3+3.7$ & 13.133 .6 & $17.9 \pm 2.8$ & $<0.001$ & $15.8 \pm 1.9$ & $10.1 \pm 2.4$ & $<0.001$ \\
\hline Limb BF\%,\% & $11.0 \pm 3.7$ & 10.722 .8 & $18.1 \pm 10.2$ & 0.017 & $12.7 \pm 2.1$ & $8.4 \pm 1.5$ & $<0.001$ \\
\hline Trunk/Limb BF\%, ratio & $1.22 \pm 0.15$ & $1.22 \pm 0.14$ & 1.10t0.24 & & $1.25+0.11$ & $1.19 \pm 0.17$ & $<0.001$ \\
\hline
\end{tabular}

Conclusion: The characteristics of fat distribution in male gout patients is more in trunk and trunk BF\% is positively correlated with sUA.

Disclosure of Interests: None declared

DOI: 10.1136/annrheumdis-2019-eular.5228

\section{SAT0416 ULTRASOUND EVALUATION IN FOLLOW-UP OF URATE-LOWERING THERAPY IN GOUT PHASE 2 (USEFUL-2): DURATION OF FLARE PROPHYLAXIS}

Esther Ebstein $^{1}{ }^{\text {, Marine Forien }}{ }^{1}$, Eleonora Norkuviene ${ }^{2}$, Pascal Richette ${ }^{3}$, Gael Mouterde $^{4}$, Claire Daien ${ }^{4}$, Hang Korng Ea ${ }^{3}$, Claire Brière ${ }^{3}$, Frederic Lioté ${ }^{3}$, Mykolas Petraitis ${ }^{2}$, Thomas Bardin ${ }^{3}$, Jeremy Ora ${ }^{3}$, Philippe Dieudé ${ }^{1}$, Sebastien Ottaviani ${ }^{1} .{ }^{1}$ Rheumatology Department, DHU FIRE, Pôle infection immunité, Bichat Hospital (APHP), Paris, France, Paris, France; ${ }^{2}$ Lithuanian University of Health Sciences, Kaunas, Rheumatology, Kaunas, Lithuania; ${ }^{3}$ centre Viggo Petersen, pole appareil locomoteur, Lariboisière Hospital (AP-HP); Inserm UMR 1132, USPC, Rheumatology, paris, France; ${ }^{4}$ Lapeyronie hospital, EA 2415 , Montpellier University, Rheumatology, Montpellier, France

Background: Recent studies showed that ultrasonography (US) could be useful for managing urate-lowering therapy (ULT) in gouty patients. In the first phase of the present study (USEFUL-1), we suggested that US was an accurate tool to follow monosodium urate (MSU) crystal dissolution under efficient ULT.

For gout flare after starting ULT, prophylaxis is recommended during the first 6 months of ULT. The duration of gout flare prophylaxis over the 6 months is consensual with a grade B recommendation. However, little is known about the probability of relapse according to the urate load modification.

Objectives: To determine whether a modification of US features of MSU crystal deposition is associated with reduced number of flares after stopping gout flare prophylaxis.

Methods: We performed a 1-year multicentre prospective study including patients with proven gout and US features of gout. The first phase of the study was a 6-month US follow-up after starting (ULT) with gout flare prophylaxis. After 6 months of ULT, gout flare prophylaxis was stopped, followed by a clinical follow-up (month [M] 6 to 12). Outcomes were the proportion of patients with relapse between M6 and M12 according to the modification of US features of gout and determining a threshold decrease in tophus size according to the probability of relapse.

Results: We included 79 patients with gout (mean [ \pm SD] age $61.8 \pm 14$ years, $91 \%$ males, disease duration $6.3 \pm 6.1$ years). Among the 49 completers at M12, 23 (47\%) experienced relapse. Decrease in tophus size $\geq 50 \%$ at $M 6$ was more frequent without than with relapse $(54 \%$ vs $26 \%, P=0.049$ ). On ROC curve analysis, a threshold decrease of $50.8 \%$ in tophus size had the best sensitivity/specificity ratio to predict relapse. Probability of relapse was increased for patients with a decrease in tophus size $<50 \%$ between baseline and M6 (OR 3.35 [95\% confidence interval 0.98; 11.44]).

Conclusion: A high reduction in US tophus size is associated with low probability of relapse after stopping gout prophylaxis. US follow-up may be useful for managing ULT and gout flare prophylaxis.

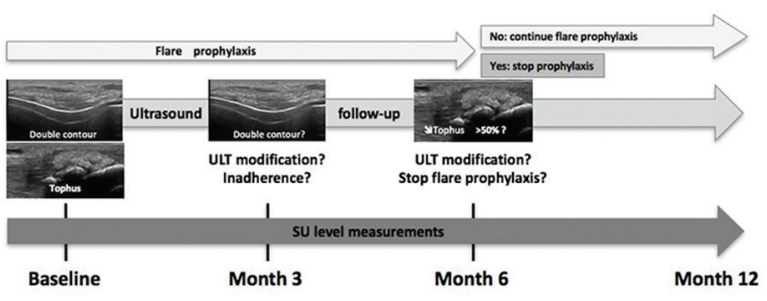

Disclosure of Interests: Esther Ebstein: None declared, Marine Forien None declared, Eleonora Norkuviene: None declared, Pascal Richette Consultant for: Grunenthal, Horizon, Speakers bureau: AstraZeneca, Gru nenthal, Gael Mouterde: None declared, Claire Daien: None declared, Hang Korng Ea: None declared, Claire Brière: None declared, Frederic Lioté Grant/research support from: institutional grants from Grunenthal, Ipsen Pharma/Menarini, Novartis, SOBI for the European Crystal Network Workshops, Consultant for: Grunenthal, Novartis, Mykolas Petraitis: None declared, Thomas Bardin Consultant for: Astrazeneca, Grunenthal, Horizon, Novartis, Speakers bureau: Astella, AstraZeneca, Grunenthal., Jeremy Ora: None declared, Philippe Dieudé: None declared, Sebastien Ottaviani: None declared

DOI: 10.1136/annrheumdis-2019-eular.1219

\section{SAT0417 HOW EFFECTIVE IS GOUT EDUCATION PROGRAMME TO IMPROVE GOUT KNOWLEDGE AMONG PRIMARY CARE DOCTORS?}

Hazlyna Baharuddin ${ }^{1}$, Nur Aini Eddy Warman ${ }^{1 *}$, Habibah Mohd Yusoof ${ }^{2}$, Ing Soo Lau ${ }^{2}$, Shereen Suyin Ch'ng ${ }^{2}$, Mollyza Mohd Zain ${ }^{2} .{ }^{1}$ Universiti Teknologi MARA, Department of Medicine, Sungai Buloh, Malaysia; ${ }^{2}$ Hospital Selayang, Department of Medicine, Batu Caves, Malaysia

Background: Gout is a potentially curable disease with simple pharmacological treatment, although its management remained suboptimal. ${ }^{1,}{ }^{2} \mathrm{~A}$ disconnection between primary care doctors who treat gout most frequently, and rheumatologists who lead the development of gout management guidelines, is one of the challenges in managing gout in primary care. $^{3} \mathrm{~A}$ concerted effort is needed to improve the quality of care of patients with gout and this includes physician education. ${ }^{4}$

Objectives: To determine the effectiveness of gout educational programme in improving gout knowledge among primary care doctors.

Methods: A gout education programme consisted of five 20-minute presentations on gout (challenges in gout, principles of gout management, treat to target, disease burden and gout diet) and a session on case discussion of two gout cases was conducted for primary care doctors. Participants were invited to complete the same set of questions distributed before (pre-test) and after (post-test) the programme. A set of 10 true/false multiple choice questions (MCQ) based on a clinical scenario of a patient with gout was constructed and vetted by two rheumatologists. Comparison between the pre-test and post-test scores were analysed using paired t-test.

Results: Forty-four primary care doctors who attended gout educational programme, answered pre-test and post-tests and the scores are shown in Table 1. The scores for recall questions were higher than application questions.The mean scores for recall questions in post-test were significantly higher compared to pre-test $(4.35 \pm 0.73$ vs $3.51 \pm 0.47, \mathrm{p}<0.01)$ but not significant for application questions ( $2.91 \pm 0.71$ vs $2.79 \pm 0.62, p=0.56$ ) Less than half of participants obtained correct answers for 13 out of 50 options in the pre-test mainly in questions 2, 3, 4, 6 and 7. (Table 1) 
Table 1. The pre-test and post-test mean scores for all participants of gout education programme.

\begin{tabular}{|c|c|c|c|c|c|c|}
\hline \multirow{2}{*}{$\begin{array}{l}\text { Question } \\
\text { no }\end{array}$} & \multirow{2}{*}{$\begin{array}{l}\text { Question } \\
\text { type }\end{array}$} & \multirow{2}{*}{$\begin{array}{c}\text { Areas of knowledge } \\
\text { tested }\end{array}$} & \multicolumn{3}{|c|}{ Mean scores, $n=30$} & \multirow{2}{*}{$\begin{array}{c}\mathrm{p}- \\
\text {-value }\end{array}$} \\
\hline & & & $\begin{array}{l}\text { Post- } \\
\text { test }\end{array}$ & $\begin{array}{l}\text { Pre- } \\
\text { test }\end{array}$ & Difference & \\
\hline 1 & Application & $\begin{array}{c}\text { Features of gout for } \\
\text { diagnosis }\end{array}$ & $\begin{array}{c}3.47 \\
\pm 0.97\end{array}$ & $\begin{array}{r}3.53 \\
\pm 1.11\end{array}$ & $-0.07 \pm 1.02$ & 0.72 \\
\hline 2 & Application & $\begin{array}{l}\text { Interpretation of } \\
\text { investigation }\end{array}$ & $\begin{array}{c}2.73 \\
\pm 0.79\end{array}$ & $\begin{array}{c}2.3 \\
\pm 1.12\end{array}$ & $0.433 \pm 0.73$ & $<0.01$ \\
\hline 3 & Application & Treatment of acute gout & $\begin{array}{c}1.97 \\
\pm 0.85\end{array}$ & $\begin{array}{c}2.27 \\
\pm 0.74\end{array}$ & $-0.30 \pm 1.01$ & 0.14 \\
\hline 4 & Application & Treatment of stable gout & $\begin{array}{c}3.47 \\
\pm 1.22\end{array}$ & $\begin{array}{c}3.07 \\
\pm 1.05\end{array}$ & $0.40 \pm 1.52$ & 0.16 \\
\hline 5 & Recall & $\begin{array}{l}\text { Indication of urate } \\
\text { lowering therapy }\end{array}$ & $\begin{array}{c}4.87 \\
\pm 0.34\end{array}$ & $\begin{array}{c}3.87 \\
\pm 0.97\end{array}$ & $0.47 \pm 0.90$ & $<0.01$ \\
\hline 6 & Recall & Allopurinol mechanism & $\begin{array}{c}3.17 \\
\pm 0.99\end{array}$ & $\begin{array}{c}2.77 \\
\pm 0.94\end{array}$ & $0.40 \pm 1.19$ & 0.08 \\
\hline 7 & Recall & Allopurinol dose initiation & $\begin{array}{c}5.00 \\
\pm 0.00\end{array}$ & $\begin{array}{r}3.53 \\
\pm 1.14\end{array}$ & $1.47 \pm 1.14$ & $<0.01$ \\
\hline 8 & Recall & Allopurinol side effects & $\begin{array}{c}4.97 \\
\pm 0.18\end{array}$ & $\begin{array}{c}4.1 \\
\pm 0.89\end{array}$ & $0.87 \pm 0.9$ & $<0.01$ \\
\hline 9 & Recall & $\begin{array}{c}\text { Non-pharmacological } \\
\text { management }\end{array}$ & $\begin{array}{c}4.00 \\
\pm 0.46\end{array}$ & $\begin{array}{c}3.6 \\
\pm 1.10\end{array}$ & $0.4 \pm 1.25$ & 0.09 \\
\hline 10 & Recall & $\begin{array}{c}\text { Medication which can } \\
\text { aggravate gout }\end{array}$ & $\begin{array}{c}4.07 \\
\pm 0.74 \\
\end{array}$ & $\begin{array}{r}3.23 \\
\pm 1.46 \\
\end{array}$ & $0.833 \pm 1.51$ & $<0.01$ \\
\hline
\end{tabular}

Conclusion: Gout educational programme for primary care doctors was effective in improving recall knowledge but not in application knowledge. Some specific areas of deficiency in gout knowledge identified were features of gout and management of acute and stable gout.

\section{REFERENCES}

[1] Richette P, Doherty M, Pascual E, et al. 2016 updated EULAR evidencebased recommendations for the management of gout. Ann Rheum Dis 2017; 76: 29-42.

[2] Abhishek A, Doherty M, Education and non-pharmacological approaches for gout. Rheumatology, 57(suppl 1), 2018; i51-58.

[3] Dalbeth N. Management of gout in primary care: challenges and potential solutions. Rheumatology. 2013; 52(1): 1549-1550

[4] JA Singh. Quality of Life and Quality of Care for patients with Gout. Curr Rheumatol Rep, 2009; 11(2): 154-160

Acknowledgement: We would like to thank the doctors who participated in gout education programme.

Disclosure of Interests: None declared

DOI: 10.1136/annrheumdis-2019-eular.7346

\section{SAT0418 ASSOCIATION BETWEEN ANEMIA AND HYPERURICEMIA: KOREAN NATIONAL HEALTH AND NUTRITION SURVEY 2016}

Yeonghee Eun $^{1}$, Eun-Jung Park ${ }^{2}$, Ji-Young Chai ${ }^{3}$, Hoon-Suk Cha ${ }^{1}$, Eun-MI Koh ${ }^{1}$, Hyungjin Kim ${ }^{1}$, Jaejoon Lee ${ }^{1}$. 'Samsung Medical Center, Department of Medicine, Seoul, Korea, Rep. of (South Korea); ${ }^{2}$ National Medical Center, Department of Medicine, Seoul, Korea, Rep. of (South Korea); ${ }^{3}$ Bundang Jesaeng General Hospital, Department of Internal Medicine, Seongnam, Korea, Rep. of (South Korea)

Background: Hyperuricemia and anemia may be related in terms of sharing comorbidities such as chronic kidney disease and cardiovascular disease. However, to our knowledge, no studies have been conducted on the relationship between two conditions. For the association of gout and anemia, there was a previous cohort study showing that patients with anemia had a 2-fold higher risk of gout compared to patients without anemia. And the risk of gout was significantly higher after adjusting for serum urate levels and kidney function. However, there is a lack of data on the relationship between anemia and hyperuricemia.

Objectives: The purpose of this study was to investigate the association between hyperuricemia and anemia using data from Korean National Health and Nutrition Examination Survey (KNHANES VII; 2016), which is representative of the Korean population.

Methods: The present study included 5887 participants aged $\geq 19$ years from KNHANES VII. Logistic regression was used to examine the association between anemia and hyperuricemia. Subgroup analysis was performed to confirm whether the association between two conditions varies according to participant characteristics.

Results: In an adjusted model that corrected for body mass index, smoking, drinking, physical activity, income, and education levels, hyperuricemia was 1.4 times more than that those without anemia $(\mathrm{HR} 1.41,95 \% \mathrm{Cl}$ 1.01-1.98). The association of anemia with hyperuricemia was not seen under 65 years of age $(\mathrm{HR} 2.68,95 \% \mathrm{Cl} 1.60-4.48)$. In addition, this association was not clear in women, but was significant in men (HR $2.62,95 \% \mathrm{Cl} 1.47-4.70)$. In the results of subgroup analysis according to comorbidities, the association of anemia with hyperuricemia was significant only in subgroups with chronic kidney disease, diabetes, hypertension, metabolic syndrome, and cardiovascular diseases. There was no association between anemia and hyperuricemia in obese subjects, but hyperuricemia risk was higher in non-obese subjects with anemia compared to those who did not have anemia.

Conclusion: In a Korean representative sample, the risk of hyperuricemia was higher for anemia. The association of anemia with hyperuricemia was more pronounced in subjects with older age, male population, and other comorbid conditions.

Disclosure of Interests: None declared

DOI: 10.1136/annrheumdis-2019-eular.7462

\section{SAT0419 HAS THE INTRODUCTION OF A PRIMARY CARE GOUT GUIDELINE RESULTED IN SERUM URIC ACID (SUA) TARGETS BEING ACHIEVED?}

Rashid Farid $^{1,1}$, Leanne Gray ${ }^{1}$, Dean John ${ }^{1}$, Daniel Holehouse ${ }^{2}$, Lesley Ottewell ${ }^{1}$. ${ }^{1}$ Royal Lancaster Infirmary, Rheumatology, Lancaster, United Kingdom; ${ }^{2}$ Bay Medical Group, Morecambe, United Kingdom

Background: Gout is the most common inflammatory arthritis thought to affect $2.4 \%$ of the UK population. A local primary care audit in 2012 suggested suboptimal gout management. In an attempt to improve gout management we introduced a local guideline which was supported by an increase in gout education to our local primary care physicians.

Objectives: To assess the impact of a local primary care gout guideline (introduced in 2015) by comparing pre-guideline audit data (2012) to post guidelines audit data (2019). To identify if the introduction of this guideline translated into a reduction in secondary care referrals for advice on gout management.

Methods: Retrospective analysis of primary care data covering all patients with active diagnosis of gout since 2015 in a large primary care medical group (list size of 30,000 patients). This data was then compared to the results of a previous audit carried out prior to introduction of guideline (2012). As well as assessing primary care data, we carried out a secondary care audit pre and post guideline introduction.

Results: Out of a population list of 30,000 patients, $650(2.1 \%)$ cases were coded as gout. $521(80 \%)$ were male and $129(20 \%)$ were female $429(66 \%)$ were on ULT. $407(94.8 \%)$ were on Allopurinol. 21(4.8\%) were on Febuxostat and only 1 patient on sulfinpyrazone.

Of those on Allopurinol, $24(5.9 \%)$ had no documented monitoring of sUA levels. Out of the remaining $383(94.1 \%), 179(46.7 \%)$ achieved target sUA of $<360$, compared to $16.7 \%$ in the previous audit. $204(53.3 \%$ had not achieve the target SUA levels. $178(46.4 \%)$ patients had had their SUA levels checked in the last year compared to $23.5 \%$ in the previous audit. 107 (28\%) had SUA levels checked in last 3 years compared to $40 \%$ in the previous audit. SUA levels were not checked in the last 3 years in $98(25.6 \%)$ compared to $36.4 \%$ in the past.

Of those on febuxostat, $14(67 \%)$ achieved target sUA levels. 7 (33\%) did not achieve target sUA levels. 10 (47\%) patients had their sUA levels checked in the last year. $7(33 \%)$ had their sUA levels checked within the last 3 years and $4(20 \%)$ had not had their sUA levels checked within the last 3 years.

No patient was prescribed more than $300 \mathrm{mg}$ allopurinol daily by their primary care physician despite the recommended dose being up to $900 \mathrm{mg}$ daily.

We found a $70 \%$ reduction in the number of referrals to secondary care for gout management over the same period of time.

Conclusion: The introduction of a local primary care gout guideline and associated education appears to have improved the number of patients achieving target serum uric acid levels as well as leading to a reduction in secondary care referrals for gout. 